But since pre-existing equitable interests of this type would remain subject to the controls involved in their specific enforcement, though they might outlast the statutory limit, they would not do so if courts of equity deemed their enforcement inequitable.

Section $6^{43}$ appears to be a sound realization of the limitations of legislation dealing with possibilities of reverter and rights of entry. Certainly the use of these instruments in the enforcement of leasehold promises does not produce the grossly inequitable results caused by their use in grants of fees. Nor need such legislation deal with the highly developed law of mortgages, where the safeguards devised to protect mortgagors and the security nature of the transaction render the problems greatly different from those involved in the Illinois proposal.44

\title{
THE LIQUIDATION OF CORPORATE OWNERSHIP INTERESTS-A FEDERAL TAX PROBLEM
}

Tax problems raised for shareholders concerned with liquidating their entire interests in a corporate enterprise have been complicated by failure of Congress and the courts to recognize the existence of a distinct, identifiable business decision which requires consistent treatment regardless of the particular method employed to accomplish disinvestment ${ }^{\mathrm{x}}$ of the capital used in the business. Basically, three alternative methods of disposal are available to the sellers of a corporate business. The conventional method of disinvestment is a statutory proceeding in liquidation and dissolution by which the corporation, usually through trustees, sells its assets and then distributes the proceeds to its share-

43 "Section 6. This Act does not invalidate or affect ( $\mathrm{r}$ ) a conveyance made for the purpose of releasing or extinguishing a possibility of reverter or right of entry or re-entry:

(2) A right of entry or the transfer of a right of entry for default in payment of rent reserved in a lease or for breach of covenant contained in a lease, where such transfer is in connection with a transfer of a reversion and the rent reserved in the lease.

(3) A right of entry or the transfer of a right of entry for default in payment of a rent granted or reserved in any deed or grant, or for breach of any covenant in any deed or grant where a rent is granted or reserved, where such transfer is in connection with a transfer of a rent so granted or of a rent so reserved; or

(4) Any rights of a mortgagee based upon the terms of the mortgage, or any right of a Trustee or a beneficiary under a trust deed in the nature of a mortgage based upon the terms of the trustless deed."

${ }_{44}$ The proposed Illinois statute concludes with a separability clause that does not require comment.

"Section 7. If any provision of this Act or the application of any provision thereto to any property, person, or circumstances is held to be invalid, such provision as to such property, person or circumstances shall be deemed to be excised from this Act, and the invalidity thereof as to such property, person, or circumstances shall not affect any of the other provisions of this Act or the application of such provision to property, persons or circumstances other than those as to which it is invalid, and this Act shall be applied and shall be effective in every situation so far as its constitutionality extends."

I The word "disinvestment" is used to mean a conversion of assets to liquid form or, as it is sometimes expressed, a negative investment. 
holders. ${ }^{2} \mathrm{~A}$ second method involves a direct transfer of the outstanding shares from shareholders to purchasers without a disturbance of the corporate entity. ${ }^{3}$ The third is a liquidation in kind to the shareholders, who may then sell the assets individually. ${ }^{4}$

Regardless of the manner of disposition, a shareholder is taxed upon a capital gain measured by the value of that part of the distribution or sale price received by him which exceeds the basis for his shares. ${ }^{5}$ When the disinvestment proceeds through trustees for a corporation there may also be a capital gains tax levied upon the company. ${ }^{6}$ This procedure of statutory liquidation through trustees results in a double tax, once to the company, then to the shareholder. ${ }^{7} \mathrm{On}$ the other hand, a double tax may be avoided by a transfer of the shares, since under this procedure no gain is attributable to the corporation although the shareholder is assessed upon his realized gain. ${ }^{8}$

This difference in treatment of statutory liquidation and disinvesting by a sale of shares may explain the uncertainty regarding the tax consequences of the third form of disinvestment-liquidation in kind. The Treasury Regulations provide that a corporation derives no taxable gain upon a liquidation in kind to its shareholders. ${ }^{9}$ This provision of the regulations for a single tax resembles the single-tax treatment of the sale-of-shares device. Little confusion would arise if the liquidation in kind were always recognized as a single-tax procedure. But despite the Treasury Regulations, some courts seem to regard the single-tax

2 "Gross Income of Corporation in Liquidation. - When a corporation is dissolved, its affairs are usually wound up by a receiver or trustees in dissolution. The corporate existence is continued for the purpose of liquidating the assets and paying the debts, and such receiver or trustees stand in the stead of the corporation for such purposes." Treas. Reg. III, $\$ 29.22(a)-20$ (I943).

3 Ig Fletcher, Cyc. Corp. $\$ 9066$ (I933).

4 Ballantine, Corporations § 3 I9 (2d ed. r946).

5 Property received by a shareholder in a liquidation is treated as payment in exchange for the stock held by the shareholder. Tax consequences of the transaction, as far as the shareholder is concerned, are identical with those in a sale or exchange of stock not connected with a liquidation situation. Internal Revenue Code, $\S \mathrm{rr}_{5}$ (c), 56 Stat. 84I (I942), 26 U.S.C.A.

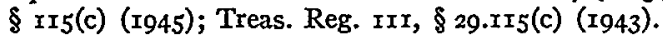

${ }^{6}$ Internal Revenue Code, $\S 22(a), 53$ Stat. 9 (I939), 26 U.S.C.A. $§ 22(a)$ (I940); Treas. Reg. III, \$ 29.22(a)-20 (I943).

7 The diminution of a shareholder's receipts upon liquidation and sale caused by the payment of a tax upon gain assessed against the corporation will prevent an actual assessment against the shareholders personally when, by virtue of such diminution, these receipts fall below the shareholder's basis for the shares. However, even in the situation where the shareholder does not pay any tax, the double tax is no less real. Individual receipts are decreased by ro per cent of the tax paid by the corporation. Were the amount of that tax paid to the individual shareholder, a tax levied upon him would take only a fraction of the additional sum received.

8 No cases have been found which disregard the corporate entity in the sale-of-shares situation in order to find a taxable gain to the vendor corporation.

9 "No gain or loss is realized by a corporation from the mere distribution of its assets in kind in partial or complete liquidation, however they may have appreciated or depreciated in value since their acquisition." Treas. Reg. III, \$ 29.22(a)-20 (I943). 
feature of liquidations in kind as an avoidance of the double tax incurred in a statutory liquidation..$^{\text {To }}$ As a consequence, a liquidation in kind may result in either a single or a double tax depending upon the suspicions of the court regarding the circumstances surrounding the liquidation.

In the only Supreme Court decision bearing directly on the problem, the taxpayer attempted to utilize the regulations concerning liquidations in kind in order to avoid the payment of a double tax. The decision introduced a substantial obstacle to the employment of the liquidation-in-kind device.

In Com'r of Int. Rev. v. Court Holding Co., ${ }^{\text {II }}$ the taxpayer corporation withdrew from an oral agreement to sell an apartment building, its only asset, after discovering that such a sale by the company would entail heavy income taxes. Then the corporation distributed the property in complete liquidation to its two sole shareholders, who sold to the same purchaser on terms identical with those of the earlier oral agreement. The Supreme Court found that the corporation incurred tax liability on the resulting gain, ${ }^{12}$ stating that "To permit the true nature of a transaction to be disguised by mere formalisms, which exist solely to alter tax liabilities, would seriously impair the effective administration of the tax policies of Congress." ${ }_{13}$

The concern of the court with "formalism" seems to have been prompted by a belief that the taxpayer was seeking an unwarranted avoidance of taxes through the use of a technical device. But the procedure adopted by the shareholders, liquidation in kind, is permissible under the Internal Revenue Code. ${ }^{14}$ The view that tax considerations should be merely collateral to the liquidation seems unrealistic. The hiring of tax attorneys and consultants is surely common-

ro Despite the single-tax treatment provided in the Treasury Regulations for liquidations in kind, the courts have displayed a readiness to impose a double tax, particularly in the case of closely-held corporations, apparently on the theory that the liquidation in kind was merely a legalistic cover-up for a statutory liquidation. This attitude may be explained by the cumulation of tax advantages available in liquidation situations. The capital gains provisions of Section $x x_{7}$ of the Internal Revenue Code, in general, enable shareholders to realize a 75 per cent net gain on liquidation, although since these advantages are today available to both individuals and corporations, they do not represent tax-avoidance in this situation. In addition, the re-allocation of income from a single corporation to several shareholders creates tax savings under a system of progressive income tax rates. Finally, the avoidance of a double tax results in further substantial savings. The decisions, however, have not made these considerations explicit but have, instead, emphasized the necessity of determining whether the corporation or the shareholder was the party actually making the sale of the assets.

These situations should be clearly distinguished from the Hollywood "collapsible" corporation type of case where the taxpayer is attempting to treat the receipt of ordinary income as a capital gain. Use of the corporation as a means of converting ordinary income to capital gain has been the subject of comment. 48 Time, No. 6, at 80 (Aug. 5, 1946).

II 324 U.S. 33I (r945).

12 The opinion creates the impression that the court thought it was exposing a well camouflaged tax-avoidance scheme. The court observed that $\$ 1,000$ received by the corporation from the purchaser prior to the liquidation was applied to the purchase price. It is possible, however, that the "crudeness" of the taxpayer's liquidation technique was a result of complete candor on the part of his counsel who apparently had no doubt as to its legality.

$$
{ }^{13} 324 \text { U.S. 331, } 334 \text { (1945). } \quad \text { I4 Treas. Reg. III, § 29.22(a)-20 (I943). }
$$


place, and businessmen often quite legitimately choose between alternative methods of dealing solely on the basis of varying tax consequences..$^{15}$ In addition, the requirement that a taxpayer in order to secure the benefits of liquidation in kind must refrain from negotiating prior to liquidation, may pose a difficult problem of evidence relating to the existence of prior negotiations with a purchaser ${ }^{16}$

The Court Holding Co. decision seems to require that shareholders, if they wish to avoid a double tax, must effectuate a liquidation in kind before instituting negotiations with outsiders for the sale of the assets. At the least, it requires that shareholders conduct the entire course of negotiation in their own names.

This requirement that shareholders must effectuate a liquidation in kind before instituting negotiations for the sale of an asset will subject shareholders to a capital gains tax before there has been an actual "realization" of gain in cash. ${ }^{17}$ Therefore, the shareholders must bear the risk of a depreciation in the value of the assets during the interval between the liquidation and the sale to others. In addition, if shareholders are denied the advantages of negotiations precedent to the liquidation, they face a possibility of retaining assets for which there is no ready market.

Consideration of the element of risk suggests a possible rationale of the Court Holding Co. case. A shareholder may be required to assume some personal risk before he can avoid the impact of a double tax. Where the shareholder does not bear any risk, the court for tax purposes may assume that the corporation is still a party to the sale transaction..$^{88}$

A recent case involving a parent-subsidiary liquidation, Fairfield S. S. Corp. v. Com'r of Int. Revis does not, however, follow a risk interpretation of the Court Holding Co. decision. In the Fairfield case, the three shareholders of a parent corporation decided to liquidate that company and the Fairfield Company, a wholly-owned subsidiary. Prior to formal liquidation the controlling shareholder hired an agent and a broker to receive offers for the subsidiary's principal asset, a ship. All parties to the negotiations understood that the asset was to be sold in the name of the parent company. A revocable offer to purchase

${ }^{15}$ See Gregory v. Helvering, 293 U.S. 465,469 (I935); United States v. Isham, 17 Wall. (U.S.) 496, 506 (1873); Chisholm v. Com'r. of Int. Rev., 79 F. 2d 14, 55 (C.C.A. 2d, 1935).

${ }^{16}$ The burden of proving that prior negotiations did not occur is placed upon the taxpayer. Wichita Terminal Elevator Co., 6 T.C. II58 (1946).

17 Note 5 supra.

${ }^{18}$ There may be some question as to the usefulness of a risk test. Under the Court Holding Co. decision a taxpayer-shareholder may avoid a double tax so long as negotiations with a specific purchaser have not been instituted prior to liquidation. Often, risk in the sense of marketability of the assets can be almost completely eliminated, particularly in the case of a closely-held concern, by a general market analysis undertaken by the shareholder while the corporation still holds the assets.

${ }^{19}$ I57 F. 2d 32 I (C.C.A. 2d, I946), cert. den. 67 S. Ct. I93 (1946). For a discussion of the case see Double Taxation upon Sale of Corporate Assets, 56 Yale L.J. 379 (1947). 
the vessel was not accepted until the ship could be transferred from the subsidiary and the parent could be authorized by its directors to sell the assets received in the liquidation. Then the offer was accepted and the purchaser received title to the property. The remainder of the assets of the subsidiary, consisting of cash and receivables, were transferred to the parent three months later. The Commissioner of Internal Revenue issued a deficiency assessment against the subsidiary based upon the gain realized from the sale of the vessel.

The taxpayer claimed that the parent had received the ship in compliance ${ }^{20}$ with Section II2(b) (6) of the Internal Revenue Code, which provides that "No gain or loss shall be recognized upon the receipt by a corporation of property distributed in complete liquidation of another corporation."zi The Tax Court, relying on the Court Holding Co. case, held that the parent had been a mere conduit for the passage of title and that the subsidiary could not be disregarded for the sole purpose of tax avoidance. ${ }^{22}$ Although affirming this decision, the Circuit Court of Appeals, speaking through Judge Learned Hand, rejected the reasoning of the Tax Court. Probably due to the careful efforts of the taxpayer's counsel, it was clear that the negotiations for the sale of the vessel in the Fairfield case were at all times on behalf of the parent corporation, not the subsidiary. It was impossible to find, as was found in the Court Holding Co. case, that the liquidation was in the nature of an afterthought.

The parent corporation in the Fairfield case satisfied a real-party-in-interest requirement by conducting the entire course of negotiation in its own name. But it did not meet the requirements of an assumption-of-risk test because the negotiations for the sale of the assets were begun prior to liquidation. The Court Holding Co. decision apparently demanded the satisfaction of both tests. Superficially, the Fairfield result, which frustrated the taxpayer's attempt to avoid a multiple tax, ${ }^{23}$ was consistent with the Court Holding Co. opinion since only one of the tests was satisfied. But the appellate court expressly rejected the Court Holding Co. decision as precedent. It follows that the court regarded an assumption-of-risk test as immaterial. The resulting interpretation of the Court Holding Co. decision limited its force to a real-party-in-interest requirement. The Fairfield opinion illustrates the confusion in this portion of the tax law, since the decision which apparently operates against taxpayers as a class may in the long run be recognized as a substantial victory for them.

The Fairfield decision was based upon a "continuity of business" test ap-

${ }^{20}$ Note 24 infra.

${ }^{2 x}$ Internal Revenue Code, $\&$ rr2(b)(6), 49 Stat. 1679 (1936), 26 U.S.C.A. \& II2(b)(6) (1945). ${ }_{23} 5$ T.C. 566 (1945).

${ }^{23}$ In addition, the taxpayer here, as well as in the Court Holding Co. case, may have been attempting to obtain the capital gains benefits available to shareholders as individualsbenefits then unavailable to corporate taxpayers under the pre-1942 law which was applicable in both of these cases. Corporations were not given the principal benefits of the capital gains provisions until 1942, 56 Stat. 843 (1942), 26 U.S.C.A. \$ II7 (I945). They have been available to individuals since I938. 52 Stat. 500 (1938), 26 U.S.C.A. § II 7 (I945). 
plicable only to parent-subsidiary liquidations under Section II2(b)(6) of the Internal Revenue Code. The Circuit Court of Appeals found that the transfer to the parent company had not been a liquidation within Section II2(b)(6) because that section "has its reason and its justification in the fact that excepted transfers are of a kind which do not result in substantial changes of interest, and that the original business is to go along as before." ${ }^{24}$ Since the parent company sold the ship after receiving it in liquidation, the court found that it had not intended to continue the business but rather had occupied the position of a trustee in liquidation for the subsidiary. ${ }^{25}$ Therefore, gain on the sale was attributable to the subsidiary. ${ }^{26}$

A "continuity of business" test is supported by related tests developed in corporate reorganization cases. ${ }^{27}$ But the purpose of the reorganization provisions of the Internal Revenue Code is to "permit corporate readjustments which otherwise would have been deterred by the imposition of taxes which appear to the business man to be oppressive and premature, ${ }^{328}$ and the problem of the courts has been, generally, to prevent a tax-free distribution of profits in the guise of a particular liquidation of assets on reorganization. In the Fairfield case, the subsidiary was completely liquidated. The transaction could have been recognized simply as a disposal by the shareholders of the assets of a family

${ }^{24} 157$ F. 2 d 321,323 (C.C.A. 2d, 1946).

${ }^{25}$ In an addendum, the Circuit Court of Appeals attempted to reinforce its opinion based upon $\S \mathrm{rI2}(\mathrm{b})(6)$ of the Internal Revenue Code by stating that the parent company also acted as a trustee in dissolution for its subsidiary - therefore a gain was realized by the subsidiary. The court did not retract its original error of relying upon $\S \mathrm{II} 2(\mathrm{~b})(6)$. That section postpones realization of gain by the recipient of a liquidation in kind until sale to a third party. It does not deal with problems of gain to the liquidating corporation. And the Fairfield Company was the liquidating corporation. See Double Taxation upon Sale of Corporate Assets, 56 Yale L.J. 379, 382 ( $\mathrm{rg47}_{94}$; Tax Notes, 32 A.B.A.J. 516 (r946). The trusteeship argument in the addendum only added to the confusion. The language quoted by the court from Regulation IO3, § I9.22(a)-2I (I940) concerns realization of gain in a statutory liquidation. The Fairfield case involved a liquidation in kind. It could have been regarded as a statutory liquidation by an application of the Court Holding Co. line of reasoning. But the addendum did not retract the court's earlier refusal to apply that case. And the addendum gave no other clue as to how a liquidation in kind, which in some unexplained, chameleon-like fashion suddenly became a statutory liquidation, could by application of $\S$ II2(b)(6) create a realized gain to a liquidated corporation.

${ }^{26}$ The Court's use of $\S$ II2(b)(6) seems technically faulty. The section deals with a gains tax levied upon a parent corporation. It does not apply to taxation of a subsidiary nor does it deal with ascertaining parties to the sale of assets. No question of a tax on the parent was before the court in the Fairfield case.

${ }^{27}$ Fahey, Income Tax Definition of "Reorganization," 39 Col. L. Rev. 933 (1939); ParentSubsidiary Problem under the Non-recognition Provisions, 34 Ill. L. Rev. 303 (I939). Courts are not unanimous in requiring satisfaction of a continuity-of-business test in $\$ 112$ (b)(6) situations. Tri-Lakes S.S. Co. v. Com'r of Int. Rev., I46 F. 2 d 970 (C.C.A. 6th, I945). In the Tri-Lakes case the subsidiary was liquidated and a tax was paid by it on the gain realized from the conversion of the assets. The money was then transferred to the parent, the court ruling that this transfer was tax-free under the provision of $\S \operatorname{II} 2(b)(6)$. Clearly there was no continuity of business here.

${ }^{28}$ Fahey, op. cit. supra note 27 , at 934 . 
holding company system and the parent company, as an intermediate corporate entity, could have been disregarded. If the taxpayer had succeeded in complying with Section $\operatorname{II2}(\mathrm{b})(6)$, only the shareholders would have been taxed upon the gain. The effect of the decision is to require a triple tax. The subsidiary must pay a capital gains tax, the parent is similarly taxed, and the shareholders are taxed again either upon dividends or upon property received in liquidation, although in the Fairfield case the tax to the parent was completely offset by capital losses sustained during the year.

A principal difficulty with the opinion, one that frequently appears in taxavoidance decisions, is that the taxpayer may have legitimately achieved the results in other ways. The parent might have transferred the subsidiary's shares to the purchaser directly, although such a solution would have involved the purchaser's willingness to pay also for assets other than the ship. An alternative method would have been to liquidate the subsidiary before negotiations for the sale, subject to the risk that a purchaser might not have been found. This element of risk, however, may have been more formal than real since, at the time of the negotiations, ships were highly marketable assets.

The Fairfield decision may tend to encourage devious solutions to liquidation problems, such as the maintenance of secrecy or informality in negotiations. Moreover, the tax bar may not unreasonably assume that the decision was governed by the more technical aspects of the transaction, such as the failure to transfer the remaining assets of the subsidiary at the same time as the vessel. The result of such emphasis on formalities may be the limiting of tax advantages to those able to afford higher-priced legal advice.

While the Fairfield decision appears to have substantially limited the effect of the Court Holding Co. case by requiring only that the shareholder conduct negotiations in its own name, a recent Tax Court decision, Acampo Winery \& Distilleries v. Com'r of Int. Rev., ${ }^{29}$ appears to have substantially eliminated even this requirement. In the Acampo case, it was impossible to find purchasers for the shares of the company although there was a good market for its assets. The corporation would not sell the assets directly because of the very large tax liability which would result, so it was decided to make a distribution in kind. Because many of the $3^{\mathrm{I} 8}$ shareholders were in the armed forces or otherwise unable to participate in person, the distribution was made to trustees acting for them. After the corporate distribution, the trustees sold the assets to a purchaser whose offer had previously been rejected by the corporation. The court denied the applicability of the Court Bolding Co. case, finding that "the negotiations which led to the sale in the present case were begun after the liquidating distribution, were carried on by trustees selected by and representing only stockholders, were not participated in by the corporation in any way, and had no important connection with any prior negotiations." $3^{\circ}$ The risk of devaluation was borne by the shareholders after they paid any capital gains taxes arising "

${ }^{29} 7$ T.C. 629 (1946). ${ }^{30}$ Ibid., at 635 . 
out of the liquidation, although such risk may have been insignificant, as it was in the Fairfield situation, in view of the ready market existing for the assets.

The Acampo decision is significant in extending the trustee device to liquidations in kind. Some earlier decisions in the lower federal courts had found that trustees in liquidation could act for the shareholders rather than the corporation. ${ }^{3 x}$ But most of these cases involved closely-held companies. The Acampo case was the first in which a court has recognized that trustees in liquidation acting for many shareholders were engaged in a bona fide business arrangement instead of a technical transaction devised solely for tax-avoidance purposes. ${ }^{32}$ If the Acampo case is followed, corporate owners may avoid the double taxation incident to dissolution through trustees for the corporation while retaining the advantages of a centralized liquidation. The practical problem in taking advantage of the decision arises in arranging the transfer so as to establish the shareholders rather than the corporation as the beneficiaries of the trusteeship in liquidation. Apparently the retention by the corporation of sufficient assets to meet outstanding obligations, pay taxes, and cover the expenses of winding up was sufficient in the Acampo case to satisfy any real-party-in-interest requirement. 33

The irreconcilable difference in treatment between a statutory liquidation and a sale of shares does not contribute to the formation of desirable tax law. But the position of a liquidation in kind, vacillating between the two extremes, reduces the disinvestment problem to complete confusion. A consistent treatment of the liquidation-in-kind situations may effect a workable result. One solution, indicated by the Fairfield and Acampo cases, would permit a shareholder in most situations to obtain the advantages of centralized and flexible liquidation while at the same time avoiding a double assessment. The shareholder would only be required to satisfy the simple requirements of the Acampo case in order to achieve a single tax. Such a solution would, as a practical

$3^{\mathrm{x}}$ Weeks v. Sibley, 269 Fed. 55 (D.C. Tex., I920); Conservative Gas Co., 30 B.T.A. 552 (I934); see also Com'r of Int. Rev. v. Merchants Nat'l Bldg. Corp., I3I F. 2 d 740, $74 \mathrm{I}$ (C.C.A. 5th, I942); Central Nat'l Bank, 25 B.T.A. II23, II 28 (I932); Jemison's Appeal, 3 B.T.A. 780, 803 (I926).

${ }^{32}$ Since a large number of shareholders were involved in the Acampo case, it is possible to minimize the importance of the decision. The strict judicial attitude in liquidation cases toward an avoidance of a corporate tax is usually manifested where a closely-held corporation is involved. The high degree of individual shareholder control present in such situations may raise an "unofficial" presumption of unwarranted tax-avoidance. Unquestionably, such a consideration cannot be completely ignored in tax cases. Nevertheless, the courts tend to emphasize the facts indicating the presence or absence of an agency or trust relationship between the shareholders and the trustees in liquidation. See Trippett v. Com'r of Int. Rev., Ir8 F. 2d 764, 765 (C.C.A. 5th, I94I); First Nat'l Bank of Greeley v. United States, 86 F. 2d 938, $94 \mathrm{I}$ (C.C.A. Ioth, 1936); Taylor Oil \& Gas Co. v. Com'r of Int. Rev., 47 F. 2d ro8, rog (C.C.A. 5th, I931); First Nat'l Bank of Wichita Falls v. Com'r of Int. Rev., 3 T.C. 203 , 216 (I944). From the agency standpoint, the Acampo case assumes considerable significance. It is far easier to find an agency relationship where there are few shareholders than where there are many.

${ }^{33} 7$ T.C. 629,636 (1946). 
matter, render obsolete the provisions relating to statutory liquidations through trustees for the corporation. ${ }^{34}$

An alternative solution based upon the Court Holding Co. decision is also feasible although it cannot affect the single-tax feature of the sale-of-shares device. By a drastic extension of that case, a double tax could be required whenever the corporation is a party to the sale negotiations in any capacity. Some degree of uncertainty may be created concerning the presence of the corporation in the transaction, but the practical effect of this uncertainty may be at least partially eliminated by placing the burden of persuasion as to this issue on the corporation.

Uniformity in all disinvestment situations, regardless of the method employed by the shareholders, could be achieved in the way of a single tax by a legislative change which would abolish any tax to the corporation upon statutory liquidation. But such a solution raises the entire question of taxes upon corporate income and for that reason the legislature might be reluctant to permit the necessary change.

To an equal extent, uniformity could be achieved if gain upon appreciated assets were recognized by the tax system as realized whenever the corporation disposed of the assets by sale, exchange, or liquidation. If this were the law, a double tax ${ }^{35}$ would result whenever shareholders disinvested and liquidated a corporation. The Internal Revenue Code today clearly requires a double tax in the case of a statutory liquidation. ${ }^{36} \mathrm{~A}$ double tax would also result in the liquidation-in-kind situation if the law were changed to recognize a taxable gain to the corporation upon disposal of its assets. The present Treasury Regulation, which provides that no gain is realized by a corporation upon assets liquidated in kind, is consistent with the reasoning of the Supreme Court expressed in a decision dealing with dividend distributions in kind. In that case, General Utilities \& Operating Co. v. Helvering, ${ }^{37}$ the corporation did not realize any gain upon distribution of the dividend in $\operatorname{kind}^{38}$ because the corporation was not

34 There is a strong possibility that the rationale of the Acampo decision, permitting trustees to act for the shareholders rather than for the corporation, would not survive an attempt to create a generally available single-tax liquidation device. Such an attempt might be prevented by courts which considered that the trusteeship for stockholders would not preclude simultaneous trusteeship for the corporation. See Chilhowee Mills, Inc. v. Com'r of Int. Rev., 4 T.C. 558, 566 (1945); Will T. Caswell v. Com'r of Int. Rev., 36 B.T.A. 816, 822 (I937).

35 The term "double tax" does not necessarily indicate a simultaneous assessment against two tax-paying entities as a result of a single transaction, but rather, the term is used to indicate the combined effect of an assessment against shareholders for all gains received upon disinvestment coupled with a gains $\operatorname{tax}$ to the corporation levied upon the disposition of appreciated property at any time during the corporate existence.

${ }^{36}$ Note 2 supra.

37296 U.S. 200 (1935).

${ }^{38}$ It is difficult to reconcile this decision with the Court Holding Co. opinion. In the General Utilities case, the taxpayer corporation refused to sell assets because of the gains tax to the corporation. But the corporation officials negotiated with the prospective purchaser and agreed to terms for the sale. The corporation distributed the assets as a dividend in kind 
selling its assets nor exchanging them as payment for a corporate debt. ${ }^{39} \mathrm{~A}$ rescission of the present Treasury Regulation accompanied by judicial or legislative reversal of the General Utilities doctrine as applied to liquidations in kind would be necessary in order to impose a double tax.

In the sale-of-shares situation it would not be necessary to tax the corporation immediately at the time the shareholders dispose of their interests. Dissolution of the corporation does not necessarily accompany disinvestment by the shareholders as it must in the statutory-liquidation and liquidation-in-kind situations. In the sale-of-shares situation a double tax is imposed if the corporation is ultimately taxed upon the gain even though the assessment is not made until final dissolution. Final dissolution must be accompanied by a statutory liquidation or by a liquidation in kind. Only if the General Utilities doctrine is rejected will the liquidation in kind result in a double tax as does the statutory liquidation. But a further change in the present tax law would be necessary to make the tax upon dissolution inescapable. The corporation's basis for any assets held by it would have to remain unaffected by the basis acquired by the purchasing shareholders. The tax-free alteration of basis for corporate assets to conform with share purchase price, as sometimes permitted today, would provide a continuing loophole for avoidance of a gains tax upon disposal of the assets by the corporation..$^{0}$

to its stockholders who sold to the same purchaser on terms identical with those of the earlier agreement. And the court rejected the Commissioner's claim for a gains tax on the corporation. The Court Holding Co. opinion did not mention the General Utilities decision, much less overrule it, despite the fact that the two cases reached opposite results in situations distinguishable only on the ground that one dealt with liquidations in kind and the other with dividends in kind.

${ }^{39}$ General Utilities \& Operating Co. v. Helvering, 296 U.S. 200, 206 (1935). The court distinguished the situation in which the corporation declares a cash dividend and pays it through a distribution of appreciated assets. In this situation the corporation realizes a gain upon distribution since it is paying a corporate debt at the appreciated rate. Interstate Realty Co. v. Com'r of Int. Rev., 25 B.T.A. 728 (I932); Bacon-McMillan Veneer Co., 20 B.T.A. $55^{6}$ (1930).

$4^{\circ}$ Under the law today, the purchaser of a corporation by use of the sale-of-shares device may enable the company to escape taxation for appreciation of the corporate assets, and at the same time he may acquire a new corporate basis for the assets equal to the share purchase price. The purchaser of the shares will immediately transfer all corporate assets to himself by use of a liquidation in kind. No capital gains tax will be incurred upon the transfer, since no gain is realized by the corporation upon a liquidation in kind, and no gain will be realized by the shareholder since purchase price of the shares presumably will equal current market value of the assets. The shareholder will reincorporate, transferring the assets to the new corporation in return for stock valued at the purchase price of the old corporation shares. As a result, the basis of the assets to the new corporation for gain and loss purposes will be the appreciated value, yet the gain will have completely escaped corporate taxation. Even apart from the method just outlined, the same result may be achieved directly according to one circuit court decision which held that the purchaser of shares who is really purchasing the assets of an entire corporation may obtain a new basis for the assets equal to the purchase price of the shares. Com'r of Int. Rev. v. Ashland Oil and Refining Co., 99 F. $2 d 588$ (C.C.A. 6th, 1938). 
The obvious difficulty with the uniform-double-tax solution just presented is that the General Utilities doctrine ${ }^{4}$ follows the accepted practice of the present tax system in adopting a conservative notion of what constitutes realization of gain..$^{2}$ Moreover, it may be undesirable to provide for a double tax in the saleof-shares situation if such a solution requires the retention of the original basis for the corporate assets in the face of a greatly disparate sales price paid by the purchasing shareholders.

Regardless of the theoretical reasoning that may support it, the difference in treatment of a statutory liquidation, a sale of shares, and a liquidation in kind seems undesirable, as evidenced by the confusion in the Fairfield opinion. From a taxpayer's standpoint, a disinvestment, regardless of the method used in its accomplishment, represents a single decision to withdraw from a business. Perhaps in other areas of the tax law, reasons exist which justify treating uniform business decisions differently as the methods employed vary. But there are no apparent reasons compelling the lack of uniformity in treatment accorded disinvestment transactions.

${ }_{4}$ The Supreme Court in the General Utilities case had no difficulty in refusing to recognize a taxable gain to the corporation realized upon the dividend in kind. Such an attitude is surprising in view of the ill-concealed horror with which the court viewed the actions of the taxpayer in the Court Holding Co. opinion. Upon facts strikingly similar to those of the General Utilities case, the Court held that the corporation realized a gain when it liquidated in kind to its shareholders. See note 38 supra.

${ }^{42}$ For a discussion and criticism of the standard concepts of realization of gain see Simons, Personal Income Taxation (1938). 